\title{
Tooth Fracture
}

National Cancer Institute

\section{Source}

National Cancer Institute. Tooth Fracture. NCI Thesaurus. Code C50777.

Broken tooth affecting any portion of tooth: root fracture, crown-root, broken tooth (crown fracture), chipped tooth. A crown fracture can involve the pulp. Tooth fracture sequelae range in severity from cosmetic defects to tooth death. Involvement of the pulp is a more important indicator of severity of tooth fracture than is the amount of the tooth affected. 